\title{
Comorbidities and medical course in a young patient diagnosed with severe obstructive sleep apnea
}

Liliana Alexandrina Grigoriu1,*, Ștefan Dumitrache Rujinski ${ }^{1,2}$, Radu Gabriel Vătășescu ${ }^{2,3}$, Miron Alexandru Bogdan ${ }^{1,2}$

1"Marius Nasta" Institute of Pneumophtisiology, Bucharest 050150, Romania

2"Carol Davila" University of Medicine and Pharmacy, Bucharest, Romania

Abstract ${ }^{3}$ Floreasca Emergency University Hospital, Bucharest, Romania

\section{English:}

We present the 6-year evolution of a young patient (32 years at diagnosis), smoker (10 pack years), diagnosed in September 2011 by cardiorespiratory polygraphy with severe obstructive sleep apnea syndrome (OSA)-apnea-hypopnea index (AHI) 82/h, mean $\mathrm{SaO}_{2} 76 \%$, which associate class II obesity (body mass index [BMI] $37.5 \mathrm{~kg} / \mathrm{m}^{2}$ ), dyslipidemia, hypertension, mixed ventilatory dysfunction with hypoxemia and hypercapnia, pulmonary hypertension, and right bundle branch block. It was administered drug treatment, oxygen therapy, and continuous positive airway pressure (CPAP) with favorable evolution. One year later, we notice a significant improvement in the severity of OSA (AHI 13/h) and significant weight loss (about $24 \mathrm{~kg}$ ). He was diagnosed with thyroid papillary carcinoma and left laterocervical node metastasis. Total thyroidectomy, treatment with radioactive iodine, and Euthirox replacement were done. In 2013, the patient presents moderate OSA (AHI 25/h) and class I obesity (BMI $\left.31.8 \mathrm{~kg} / \mathrm{m}^{2}\right)$. Withdrawal of CPAP on its own initiative and weight gain (BMI $43 \mathrm{~kg} / \mathrm{m}^{2}$ ) causes clinical deterioration in 2014, with diurnal drowsiness, dyspnea at rest, peripheral edema, hypoxemia, and hypercapnia, requiring admission. The cardiorespiratory polygraphic evaluation highlights severe OSA with AHI 84/h. Evolution was favorable with medication, oxygen therapy, and CPAP. Over the next 3 years, the patient continues CPAP treatment at home, but variations in body weight help improve or worsen OSA severity.

Keywords

obstructive sleep apnea syndrome $\cdot$ comorbidities $\cdot$ continuous positive airway pressure

\section{Comorbidități și evoluție la un pacient tânăr diagnosticat cu sindrom de apnee în somn obstructiv sever}

Rezumat

\begin{abstract}
Romanian:
Prezentăm evoluția timp de 6 ani a unui pacient tânăr (32 de ani la momentul diagnosticului), fumător (10PA), diagnosticat în septembrie 2011 prin poligrafie cardiorespiratorie cu Sindrom de Apnee în Somn de tip Obstructiv (OSA) sever-index apnei-hipopnei (IAH) 82/h, SaO 2 medie $76 \%$, care asocia obezitate grad II (IMC $37.5 \mathrm{~kg} / \mathrm{m}^{2}$ ), dislipidemie, hipertensiune arterială, disfuncție ventilatorie mixtă cu hipoxemie și hipercapnie, hipertensiune pulmonară, bloc de ramură dreaptă. S-a administrat tratament medicamentos, oxigenoterapie și presiune pozitiva continua (CPAP) cu evoluție favorabilă. După un an observăm ameliorarea semnificativă a severității OSA (IAH 13/h) și scădere ponderală importantă (aproximativ 24 Kg). Este diagnosticat cu carcinom papilar tiroidian și metastază ganglionară laterocervicală stângă. S-a realizat tiroidectomie totală, tratament cu iod radioactiv și substitutiv cu Euthirox. În 2013 prezintă OSA moderat (IAH 25/h) și obezitate grad I (IMC $\left.31.8 \mathrm{~kg} / \mathrm{m}^{2}\right)$. Renunțarea la CPAP din proprie inițiativă și creșterea în greutate (IMC 43kg/2) determină deteriorare clinică (în 2014) cu somnolență diurnă, dispnee de repaus, edeme gambiere, hipoxemie și hipercapnie, necesitand internare. Evaluarea poligrafică cardiorespiratorie evidențiază OSA sever cu IAH 84/h. Cu tratament medicamentos, oxigenoterapie și CPAP evoluția a fost favorabilă. În următorii 3 ani, pacientul continuă tratamentul cu CPAP la domiciliu, însă variațiile în greutatea corporală contribuie la ameliorarea sau agravarea severității OSA.
\end{abstract}

Cuvinte-cheie

Sindrom de apnee în somn de tip obstructiv (OSA) • comorbidități • presiune pozitivă continuă (CPAP)

${ }^{*}$ Corresponding author: Liliana Alexandrina Grigoriu

E-mail: alexalili@yahoo.com

ว Open Access. @ 2019 Alexandrina Grigoriu et al., published by Sciendo

(ख) Br.NC-ND This work is licensed under the Creative Commons Attribution-NonCommercial-NoDerivs 4.0 License. 


\section{Introduction}

Obstructive sleep apnea (OSA) is a common disorder characterized by involuntary pauses in breathing during sleep as a consequence of intermittent upper airway obstruction. Patients with this disease are loud snorers, usually obese, who experience excessive diurnal sleepiness. Stopping breathing during sleep, accompanied by decreased oxyhemoglobin level, cause disrupted, uncomfortable sleep, and activation of the sympathetic system with cardiovascular (1-3) and metabolic $(4,5)$ repercussions. OSA may be associated with multiple comorbidities such as cardiovascular diseases, diabetes, dyslipidemia, chronic obstructive pulmonary disease (COPD), and obesity hypoventilation syndrome. Regarding the relationship with cardiovascular diseases, OSA is an independent risk factor for systemic hypertension, congestive heart failure, myocardial ischemia, arrhythmias, stroke, and sudden cardiac death (6-11).

There are close relationships between body weight and OSA, and weight loss can improve the severity of the disease and the metabolic disorders observed in both OSA and obesity $(12,13)$.

\section{Case Report}

We present the 6 years medical course of a 32-year-old patient, smoker (10 pack years), who was hospitalized in September 2011 for dyspnea at minimal effort, productive cough, and excessive diurnal sleepiness (Epworth 20/24). The patient also complains of morning headache, snoring, and nocturia.

The clinical examination revealed an obese (abdominal/ visceral type) and sleepy patient (body mass index [BMI] 37.5 $\mathrm{kg} / \mathrm{m}^{2}$-obesity class II), who present bilateral bronchial rales, symmetric bilateral peripheral edema, severe hypoxemia $\left(\mathrm{PaO}_{2} 40 \mathrm{~mm} \mathrm{Hg}\right)$, mild hypercapnia $\left(\mathrm{PaCO}_{2} 60 \mathrm{~mm} \mathrm{Hg}\right)$, oxyhemoglobin saturation $\left(\mathrm{SaO}_{2}\right) 83 \%$ in room air, and systemic arterial hypertension $150 / 90 \mathrm{~mm} \mathrm{Hg}$. The pulmonary function test showed a severe mixed ventilatory dysfunction (forced vital capacity (FVC) 66\%, forced expiratory volume in 1 seconde $\left(F E V_{1}\right) 48 \%$ of predicted values, $F E V_{1} / F V C$ $62 \%$ ) and an electrocardiogram with sinus rhythm, heart rate $78 / \mathrm{min}$, right bundle branch block. Biologically, we notice leukocytosis $12 \times 10^{3} / \mathrm{mm}^{3}$ with neutrophilia, mild inflammatory syndrome (erythrocyte sedimentation rate: $35 \mathrm{~mm}$ at $1 \mathrm{~h}$ ), and mixed dyslipidemia without any other biological changes. Cardiorespiratory polygraphy was performed and the patient was diagnosed with severe OSA, apnea-hypopnea index $(\mathrm{AHI}) 82 / \mathrm{h}$ of sleep, with frequent and important desaturations during sleep (oxygen desaturation index $80 / \mathrm{h}$, lowest $\mathrm{SaO}_{2}$ $46 \%$, average $\mathrm{SaO}_{2} 76 \%$ ).
At chest X-ray, we can observe cardiomegaly, bumping of the middle cardiac arc, and accentuation of bilateral basal interstitial markings (Figure 1). Minimal bilateral cylindrical bronchiectasis and pulmonary artery trunk enlargement (Figure 2) are described at chest computed tomography scan. A transthoracic echocardiography was performed and found enlarged right cardiac cavities: right ventricle $(40 \mathrm{~mm})$, right

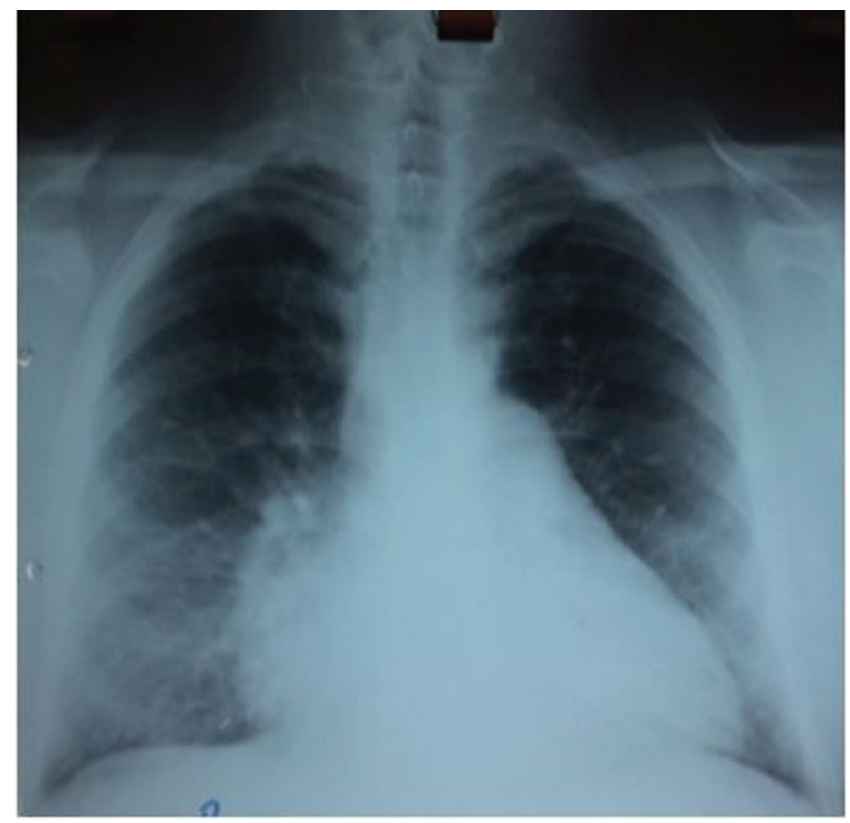

Figure 1. Chest X-ray illustrating, accentuation of bilateral basal interstitial markings, bumping of the middle cardiac arc and cardiomegaly.

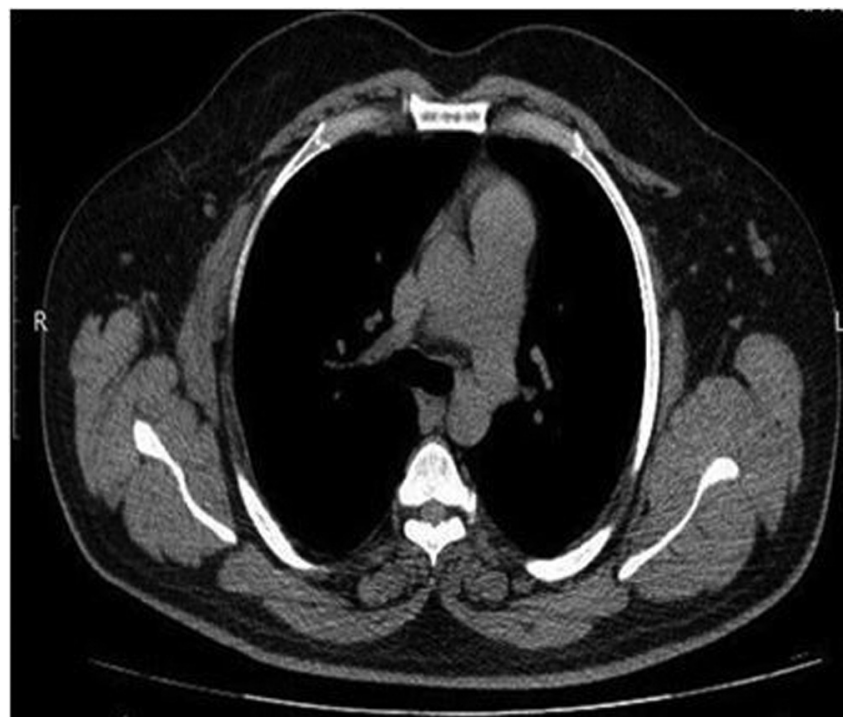

Figure 2. Chest CT scan showing enlargement of pulmonary artery trunk. 
atrium $(50 \mathrm{~mm})$, a conserved systolic left ventricle function with normal ejection fraction (55\%), mitral regurgitation grade I/IV, tricuspid regurgitation grade I/IV, tricuspid annular plane systolic excursion (TAPSE) $24 \mathrm{~mm}$, and moderate pulmonary arterial hypertension (systolic pulmonary arterial pressure $\sim 53 \mathrm{~mm} \mathrm{Hg}$ ).

The working diagnosis was cardiorespiratory decompensation with hypercapnic respiratory failure and cor pulmonale due to an infectious (probably viral) exacerbation of a not well-defined obstructive pulmonary disease at a patient with OSA and obesity with alveolar hypoventilation. The patient had a mixed ventilatory dysfunction; the restrictive component could be explained by the abdominal obesity while the obstructive one may be the result of a chronic pulmonary stasis (diastolic cardiac dysfunction at a patient with metabolic syndrome and severe OSA), the existence of bronchiectasis and smoking history. The patient has no history of familial or personal food or drug allergy or atopic disease (rhinitis/conjunctivitis).

Pulmonary hypertension is mainly due to severe sleep apnea and obesity hypoventilation syndrome.

It was initiated treatment with continuous positive airway pressure (CPAP), additional oxygen therapy, bronchodilators, antibiotic, diuretic, enzyme conversion inhibitor with the relief of symptoms, and elimination of hydrosaline retention. The patient leaves the hospital with the indication of weight loss and CPAP at home (CPAP pressure was established at $13 \mathrm{~cm}$ $\mathrm{H}_{2} \mathrm{O}$ after autotitration, with residual $\mathrm{AHI}<5 / \mathrm{h}$ and average nocturnal $\mathrm{SaO}_{2} \sim 90 \%$ ).

The efficacy of CPAP at this patient may be explained by the correction of intermittent hypoxemia secondary to a severe OSA and the elimination of hydrosaline retention.

One year later, in October 2012, the patient loses $24 \mathrm{~kg}$ in weight with BMI at $29.1 \mathrm{~kg} / \mathrm{m}^{2}$ (overweight) and the cardiorespiratory polygraphy showed a mild sleep apnea syndrome (AHI 13/h). The patient was no longer sleepy and did not use CPAP treatment anymore.

He developed left laterocervical adenopathy and he was diagnosed with thyroid papillary carcinoma metastasis by adenopathy biopsy and immunohistochemical examination. Total thyroidectomy and treatment with radioiodine, and substitution with Euthyrox were done.

In February 2013, the patient presents moderate OSA (AHI $25 / \mathrm{h}$, average nocturnal $\mathrm{SaO}_{2} 94 \%$ ), a BMl of $31.8 \mathrm{~kg} / \mathrm{m}^{2}$ (grade I obesity). He gains weight (BMI $43 \mathrm{~kg} / \mathrm{m}^{2}$ ), so, in May 2014, he was hospitalized for severe dyspnea, $\mathrm{SaO}_{2} 86 \%$ in room air, $\mathrm{PaO}_{2} 44 \mathrm{~mm} \mathrm{Hg}$ and hypercapnia $\left(\mathrm{PaCO}_{2} 62 \mathrm{mmHg}\right)$, bilateral peripheral edema (right heart decompensation), sleepiness, and severe OSA (AHI 84/h). Symptoms have been relieved after drug treatment, bilevel pressure ventilation, and additional oxygen therapy. The patient continues CPAP therapy at home.
In April 2016, severe OSA persists with $\mathrm{AHI} 76 / \mathrm{h}$, oxigen desaturation index (ODI) $81 / \mathrm{h}$, average nocturnal $\mathrm{SaO}_{2} 89 \%$, BMI $36 \mathrm{~kg} / \mathrm{m}^{2}$. The echocardiography reveals moderate pulmonary hypertension (systolic pulmonary arterial pressure $\sim 53 \mathrm{~mm} \mathrm{Hg}$ ).

The patient was readmitted in March 2017 for dyspnea at minimal effort, $\mathrm{SaO}_{2} 88 \%-89 \%$ in room air, bilateral peripheral edema, hypoxemia $\left(\mathrm{PaO}_{2} 51 \mathrm{~mm} \mathrm{Hg}\right)$, and without hypercapnia $\left(\mathrm{PaCO}_{2} 43.5 \mathrm{~mm} \mathrm{Hg}\right)$. Pulmonary function tests revealed moderate mixed respiratory dysfunction with $\mathrm{FEV}_{1}$ at $52.1 \%$ of predicted values, FVC at $70 \%, \mathrm{FEV}_{1} / \mathrm{FVC} 64.6 \%$, and transfer factor of the lung for carbon monoxide (TLCO) slightly decreased $(67 \%$ of predicted value). A cardiorespiratory polygraphic recording showed severe OSA (AHI 96.9/h) with ODI $116 / \mathrm{h}$, lowest $\mathrm{SaO}_{2} 55 \%$, and average $\mathrm{SaO}_{2} 84 \%$. The BMI was $42 \mathrm{~kg} /{ }^{2}$, so we can notice worsening of sleep apnea as a consequence of weight gain. The patient was treated with CPAP, oxygen therapy, bronchodilators, diuretics, with clinical improvement.

\section{Discussion}

We presented a young patient diagnosed with severe OSA associated with obesity and secondary alveolarhypoventilation, with repeated cardiorespiratory decompensations with hypercapnic respiratory failure and congestive heart failure with hydrosaline retention, induced by a tracheobronchial viral infection and/or non-compliance with the prescribed CPAP therapy and dietetic regimen.

The presence of a severe form of OSA explains the efficacy of CPAP therapy in a patient with hypercapnia. Multiple pathophysiological pathways could be responsible for the mixed ventilatory limitation found at this patient: a restrictive pattern linked to the abdominal obesity and an obstructive one, probably due to a chronic pulmonary stasis (diastolic cardiac dysfunction in an obese, hypertensive, and dyslipidemic patient), systemic inflammation (OSA-induced intermittent hypoxemia, metabolic syndrome), and smoking. Late-onset, non-atopic asthma at an obese patient cannot be ruled out; a low TLCO is, however, not in favor of this hypothesis. The young age and the quantum of tobacco use make the diagnostic of COPD less probable in a patient without a deficit of alpha-1 antitrypsin (not yet determined).

OSA-induced fragmented sleep and intermittent hypoxemia in association with the systemic inflammation linked to obesity or metabolic syndrome could represent risk factors in developing cancer. However, there are no consistent data proving a relationship between thyroid cancer and sleep apnea.

It was demonstrated that pulmonary arterial hypertension is present in patients with sleep apnea, even when COPD is 


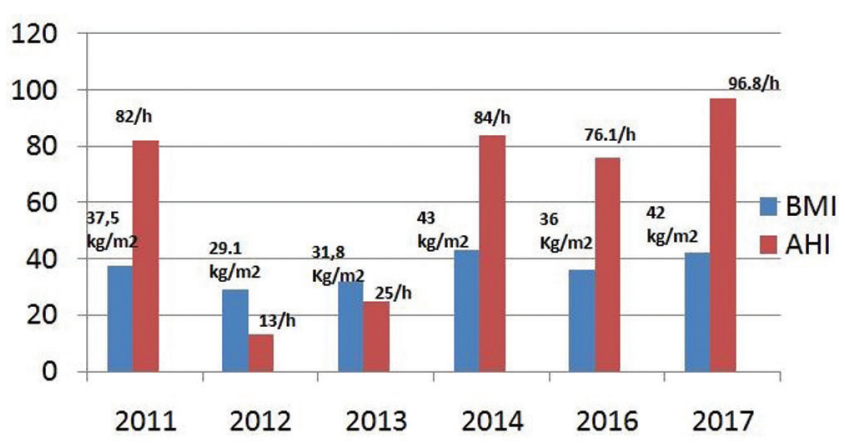

Figure 3. Variation of $\mathrm{BMI}$ and $\mathrm{AHI}$ over time.

absent, and seems to be related to the severity of obesity and its respiratory mechanical consequences (14). The development of pulmonary hypertension in patients with sleep apnea is a poor prognostic sign with repercussion on quality of life and mortality.

During 6 years of follow up, this patient experienced changes in body weight that influenced the severity of OSA. The significant decrease in body weight as a consequence of the occurrence of thyroid cancer led to significant improvement in sleep apnea severity and related symptoms and the patient discontinued CPAP therapy. Subsequently, weight gain caused worsening of OSA; the lack of CPAP therapy and poor adherence to the dietetic regimen determined multiple hospital admissions. The hydrosaline retention causes a nocturnal rostral fluid shift, with a consecutive worsening of upper airway obstruction and increase in OSA severity.

Figure 3 illustrates the changes in body weight and OSA severity within 6 years-a directly proportional relationship between body weight and severity of OSA is noted.

\section{Conclusions}

OSA is a complex disease that usually associates multiple comorbidities, especially cardiovascular and metabolic, but recent data suggest potentials associations between OSA and various types of cancer.

A mixed respiratory dysfunction may exist in OSA and obese patients; multiple pathophysiological pathways are involved.

Obesity remains the main risk factor for both OSA and cardiometabolic complications. Changes in body weight influence significantly the severity of OSA. In patients with obesity hypoventilation syndrome and severe OSA, CPAP therapy may be sufficient in correcting gas exchanges.

\section{References}

1. Bradley TD, Floras JS. Obstructive sleep apnea and its cardiovascular consequences. Lancet. 2009;373(9657): 82-93.

2. Somers VK, White DP, Amin R, Abraham WT, Costa F, Culebras A, et al. Sleep apnea and cardiovascular disease. Journal of the American College of Cardiology. 2008;52: 686-717.

3. Parish JM, Somers VK. Obstructive sleep apnea and cardiovascular disease. Mayo Clinic Proceedings. 2004;79(8): 1036-1046.

4. Lam JC, Mak JC, Ip MS. Obesity, obstructive sleep apnoea and metabolic syndrome. Respirology. 2012;17(2): 223-236.

5. Aurora RN, Punjabi NM. Sleep apnea and metabolic dysfunction: Cause or co-relation? Sleep Medicine Clinics. 2007;2(2): 237-250.

6. Peppard PE, Young T, Palta M, Skatrud J. Prospective study of the association between sleep-disordered breathing and hypertension. The New England Journal of Medicine. 2000;342: 1378-1384.

7. Yaggi HK, Concato J, Kernan WN, Lichtman JH, Brass LM, Mohsenin V. Obstructive sleep apnea as a risk factor for stroke and death. The New England Journal of Medicine. 2005;353: 2034-2041.

8. Shah NA, Yaggi HK, Concato J, Mohsenin V. Obstructive sleep apnea as a risk factor for coronary events or cardiovascular death. Sleep Breath. 2009;14: 131-136.

9. Mehra R, Benjamin EJ, Shahar E, Gottlieb DJ, Nawabit R, Kirchner HL, et al. Association of nocturnal arrhythmias with sleep-disordered breathing: the Sleep Heart Health study. American Journal of Respiratory and Critical Care Medicine. 2006;173: 910-916.

10. Peled N, Abinader EG, Pillar G, Sharif D, Lavie P. Nocturnal ischemic events in patients with obstructive sleep apnea syndrome and ischemic heart disease: Effects of continuous positive air pressure treatment. Journal of the American College of Cardiology. 1999;34: 1744-1749.

11. Gami AS, Olson EJ, Shen WK, Wright RS, Ballman KV, Hodge DO, et al. Obstructive sleep apnea and the risk of sudden cardiac death: A longitudinal study of 10,701 adults. Journal of the American College of Cardiology. 2013;62: 610-616.

12. Romero-Corral A, Caples SM, Lopez-Jimenez F, Virend K. Interactions between obesity and obstructive sleep apnea. Implications for treatment. Chest. 2010;137(3): 711-719.

13. Newman AB, Foster G, Givelber R. Progression and regression of sleep-disordered breathing with changes in weight: the Sleep Heart Health Study. Archives of Internal Medicine. 2005;165: 2408-2413.

14. Bady E, Achkar A, Pascal S, Orvoen-Frija E, Laaban JP. Pulmonary arterial hypertension in patients with sleep apnoea syndrome. Thorax. 2000;55(11): 934-939. 